TONY BUSH

Professor of Educational Leadership of Warwick, Faculty of Social Sciences

GOR SARGSYAN

Doctor of economics

\title{
EDUCATIONAL LEADERSHIP AND MANAGEMENT: THEORY, POLICY, AND PRACTICE
}

There is great interest in educational leadership in the early part of the 21st century because of the widespread belief that the quality of leadership makes a significant difference to school and student outcomes. There is also increasing recognition that schools require effective leaders and managers if they are to provide the best possible education for their learners. Schools need trained and committed teachers but they, in turn, need the leadership of highly effective principals and support from other senior and middle managers. While the need for effective leaders is widely acknowledged, there is much less certainty about which leadership behaviors are most likely to produce favourable outcomes. I examine the theoretical underpinnings for the field of educational leadership and management, assess different leadership models, and discuss the evidence of their relative effectiveness in developing successful schools.

Key words and expressions: education, skills, educational leadership, typology of management, effective leaders

In many parts of the world, including Armenia, there is recognition that schools require effective leaders and managers if they are to provide the best possible education for their learners. As the global economy gathers pace, more governments are realizing that their main assets are their people and that remaining, or becoming, competitive depends increasingly on the development of a highly skilled workforce. This requires trained and committed teachers but they, in turn, need the leadership of highly effective principals and the support of other senior and middle managers $[2,34]$.

The field of educational leadership and management is pluralist, with many competing perspectives and an inevitable lack of agreement on the exact nature of the discipline. One key debate has been whether educational leadership is a distinct field or simply a branch of the wider study of management. The author's view is clear and consistent, having been articulated for more than 20 years. While education can learn from other settings, educational leadership and management has to be centrally concerned with the purpose or aims of education. These purposes or goals provide the crucial sense of direction to underpin school management. Unless this link between purpose and management is clear and close, there is a danger of 'managerialism', "a stress on procedures at the expense of educational purpose and values" [3, 78].

The process of deciding on the aims of the organization is at the heart of educational management. In most schools, aims are decided by the principal, often working in association with the senior management team (SMT) and perhaps also with the school governing body (SGB). However, school aims are strongly influenced by 
pressures from the external environment, and particularly from the expectations of government, often expressed through legislation or formal policy statements. Schools may be left with the residual task of interpreting external imperatives rather than determining aims on the basis of their own assessment of learner needs. The key issue here is the extent to which school managers are able to modify government policy and develop alternative approaches based on school-level values and vision. Do they have to follow the script, or can they ad lib? [4, 54]

\section{Distinguishing educational leadership and management}

The concept of management overlaps with that of leadership, a notion of great contemporary interest in most countries in the developed world. It is also reflected in contemporary South African discourse, notably in the establishment of the Matthew Goniwe School of Leadership and Governance (MGSLG) in 2003 and in the title of the new pilot national qualification for school principals, the Advanced Certificate in Education: School Leadership, being piloted from 2007. However, despite these developments management remains the dominant term in the debate about aspects of school organisation.

Managing is maintaining efficiently and effectively current organisational arrangements. While managing well often exhibits leadership skills, the overall function is toward maintenance rather than change. I prize both managing and leading and attach no special value to either since different settings and times call for varied responses. Day et al.'s (2001) study of twelve 'effective' schools leads to the discussion of several dilemmas in school leadership. One of these relates to management, which is linked to systems and 'paper', and leadership, which is perceived to be about the development of people. Bush (1998; 2003) links leadership to values or purpose while management relates to implementation or technical issues.

Leadership and management need to be given equal prominence if schools are to operate effectively and achieve their objectives. "Leading and managing are distinct, but both are important ... The challenge of modern organisations requires the objective perspective of the manager as well as the flashes of vision and commitment wise leadership provides" [8, 65].

However, the nature of that work should reflect the school context and, in particular, its needs at any one time. For example, South Africa's underperforming schools $[40,97]$ require a greater emphasis on basic management, making the organisation functional, rather than a visionary approach. This may involve ensuring regular and timely attendance by learners and educators, maintaining order and discipline in classrooms, and proving adequate resources to enable learning to take place. Once schools are functional, leaders can progress to developing vision, and outlining clear aims and policies, with the confidence that systems are in place to secure their implementation.

\section{Conceptualizing educational leader- ship and management}

While there is global interest in leadership and management, because of its perceived importance in developing and maintaining successful schools and education systems, there is much less clarity about which leadership behaviours are most likely to produce the most favourable outcomes. Awareness of alternative approaches is essential to provide a set of tools from which discerning leaders can choose when facing problems and dealing with day-to-day issues. This section provides an overview of the main models of educational leadership 
and links them to similar models of educational management [2;5;9].

The implementation of the South African Schools Act (SASA) (1996) and similar moves towards self-management in many other countries, have led to an enhanced emphasis on the practice of educational leadership and management [10, 87]. Principals are inundated with advice from politicians, officials, academics and consultants, about how to lead and manage their schools. Many of these prescriptions are atheoretical in the sense that they are not underpinned by explicit values or concepts [4;6]. As we shall see later, however, governments may use conceptual language while shifting its meaning to support their own politically inspired intentions.

The models discussed in this section should be regarded as alternative ways of portraying events. The existence of several different perspectives creates what Bolman and Deal [41] describe as 'conceptual pluralism: a jangling discord of multiple voices'. Each theory has something to offer in explaining behaviour and events in educational institutions. The perspectives favoured by managers, explicitly or implicitly, inevitably influence or determine decision-making. Morgan [25, 89] uses 'metaphors' to explain the complex character of organisational life and notes that 'any theory or perspective that we bring to the study of organization and management, while capable of creating valuable insights, is also incomplete, biased and potentially misleading'.

The various theories of educational leadership and management reflect very different ways of understanding and interpreting events and behaviour in schools and colleges. In this sense, they demonstrate the different origins and epistemologies of the discipline. They also represent what are often ideologically based, and certainly divergent, views about how educational institutions ought to be managed. The models discussed in this section are broad compilations of the main theories of educational leadership and management and are based on a systematic review of the international and South African literature and research (Bush \& Glover, 2002; Bush, 2003; Bush etat, 2006).

\section{Models of educational leadership and management}

The author has presented and classified theories of educational management for over 20 years $[4,67]$. This work categorises the main theories into six major models: formal, collegial, political, subjective, ambiguity, and cultural (see Table 1).

More recently, he has reviewed concepts of educational leadership, notably in work undertaken for the English National College for School Leadership [15;18]. The literature on leadership has generated a number of alternative, and competing, models. Some writers have sought to cluster these various conceptions into a number of broad themes or 'types'. The best known of these typologies is that by Leithwood, Jantzi and Steinbach (1999), who identified six 'models' from their scrutiny of 121 articles in four international journals. Bush and Glover (2002) extended this typology to eight models. These are among the nine leadership models shown in Table 1, alongside the management models mentioned earlier.

Table 1 Typology of management and leadership models (Bush, 2003)

\begin{tabular}{ll}
\hline $\begin{array}{c}\text { Management } \\
\text { model }\end{array}$ & Leadership model \\
\hline Formal & Managerial \\
Collegial & Participative \\
& Transformational \\
& Interpersonal \\
Political & Transactional
\end{tabular}




$\begin{array}{ll}\text { Subjective } & \text { Post-modern } \\ \text { Ambiguity } & \text { Contingency } \\ \text { Cultural } & \text { Moral } \\ & \text { Instructional }\end{array}$

In the rest of this section I examine the leadership models considered to be most relevant to the Armenian context.

Managerial leadership

Leithwood et al [17] define this model as:

Managerial leadership assumes that the focus of leaders ought to be on functions, tasks and behaviours and that if these functions are carried out competently the work of others in the organisation will be facilitated. Most approaches to managerial leadership also assume that the behaviour of organisational members is largely rational. Authority and influence are allocated to formal positions in proportion to the status of those positions in the organisational hierarchy.

This definition is remarkably close to that given for 'formal models' in the author's trilogy of books on this topic (Bush, 1986; 1995; 2003).

Caldwell [16] argues that managers and leaders of self-managing schools must be able to develop and implement a cyclical process involving seven managerial functions:

$>$ goal setting;

$>$ needs identification;

$>$ priority-setting;

$>$ planning;

$>$ budgeting;

$>$ implementing; and

$>$ evaluating.

It is significant to note that this type of leadership does not include the concept of vision, which is central to most leadership models. Managerial leadership is focused on managing existing activities successfully rather than visio-ning a better future for the school. This approach is very suitable for school leaders working in centralised systems as it prioritises the efficient implementation of external imperatives, notably those pre scribed by higher levels within the bureaucratic hierarchy.

Bureaucracy, and by implication managerial leadership, is the preferred model for many education systems, including Apartheid South Africa (Seba-kwane, 1997). One example of managerial leadership is 'scientific management' [20, 43]. This dated model still 'predominates in the writing on education management in South Africa' [21, 39]. In a review of other literature, they say that this approach is associated with 'authoritarian, hierarchical and inaccessible management styles' and that the principal's authority is perceived to be 'god-given' and 'juridical'. This model can be regarded as the starting point for the study and practice of educational management, in South Africa, Europe, and North America.

Sebakwane $[52,60]$, based on research conducted in the $1980 \mathrm{~s}$, claims that scientific management was transferred from industrial corporations to South African black schools 'to bring control over teachers and students at a time when the system of education of blacks was characterized by massive student and teacher protests'. This evidence is consistent with the model described by McLennan \& Thurlow (2003).

Despite its association with the previous dispensation, managerial leadership remains important for 21st century South Africa. As noted above, achieving functional schools is an essential requirement if learning is to take place. Effectiveness requires calm and orderly schools and classrooms.

Managerial leadership has certain advantages, notably for bureaucratic systems, but there are difficulties in applying it too enthusiastically to schools and colleges because of the professional role of teachers. If principals and educators do not 'own' innovations but are simply required to implement externally imposed changes, 
they are likely to do so without enthusiasm, leading to possible failure [3, 43].

Transformational leadership

Bush (2003) links three leadership models to his 'collegial' management model. The first of these is 'transformational leadership'.

This form of leadership assumes that the central focus of leadership ought to be the commitments and capacities of organisational members. Higher levels of personal commitment to organisational goals and greater capacities for accomplishing those goals are assumed to result in extra effort and greater productivity [16, 9]. Leithwood (1994) conceptualises transformational leadership along eight dimensions:

> building school vision;

> establishing school goals;

> providing intellectual stimulation;

$>$ offering individualised support;

$>$ modelling best practices and important organisational values;

$>$ demonstrating high performance expectations;

creating a productive school culture; and

$>$ developing structures to foster participation in school decisions. Caldwell and Spinks (1992:4950) argue that transformational leadership is essential for autonomous schools:

Transformational leaders succeed in gaining the commitment of followers to such a degree that ... higher levels of accomplishment become virtually a moral imperative. In our view a powerful capacity for transformational leadership is required for the successful transition to a system of self-managing schools.

The transformational model is comprehensive in that it provides a normative approach to school leadership, which focuses primarily on the process by which leaders seek to influence school outcomes rather than on the nature or direction of those outcomes. However, it may also be criticised as being a vehicle for control over teachers and more likely to be accepted by the leader than the led (Chirichello 1999). Allix (2000) goes further and alleges that transformational leadership has the potential to become 'despotic' because of its strong, heroic and charismatic features. He believes that the leader's power ought to raise 'moral qualms' and serious doubts about its appropriateness for democratic organisations.

As we noted earlier, politicians and bureaucrats are inclined to use the language of 'transformation' to achieve their own policy objectives. The English system, for example, increasingly requires school leaders to adhere to government prescriptions, which affect aims, curriculum content and pedagogy as well as values. There is "a more centralised, more directed, and more controlled educational system [that] has dramatically reduced the possibility of realising a genuinely transformational education and leadership" (Bottery, 2001:215).

In South Africa, 'transformation' has a special meaning linked to the need to convert the previous stratified system into a new framework stressing equity and redress.

It was a case of a new government having to take on restructuring and redefining a whole system, to achieve the major aim of quality education for all ... the initial way the task was addressed was positive, holistic and put up-front the values of equity, access, transparency and democracy (Department of Education, 2007). However, there is a chasm between the rhetoric and the reality of transformation. Lemon [13, 
43] is one of several writers who claim that national policies have been rich in the political symbolism of equity and redress but with 'very limited implementation of change on the ground'.

The Task Team on Education Management Development (Department of Education, 1996:29) observes that 'real transformation will depend on the nature and quality of internal management. Self-management must be accompanied by an internal devolution of power within the school and by transformational leadership'.

A transformational leadership approach has the potential to engage all stakeholders in the achievement of educational objectives. The aims of leaders and followers coalesce to such an extent that it may be realistic to assume a harmonious relationship and a genuine convergence leading to agreed decisions. In the South African context, 'transformation' requires action at all levels and there are limits to what principals can achieve in the absence of appropriate physical, human, and financial resources.

Participative leadership

"Participative leadership ... assumes that the decision-making processes of the group ought to be the central focus of the group" (Leithwood et ah, 1999:12). This model is underpinned by three assumptions:

participation will increase school effectiveness;

participation is justified by democratic principles; and

in the context of site-based management, leadership is potentially available to any legitimate stakeholder [12, 14].

Sergiovanni (1984:13) points to the importance of a participative approach. This will succeed in 'bonding' staff together and in easing the pressures on school principals. "The burdens of leadership will be less if leadership functions and roles are shared and if the concept of leadership density were to emerge as a viable replacement for principal leadership".

The participative model is consistent with the democratic values of the new South Africa. The introduction of SGBs for all schools, and the greater prominence given to SMTs, suggests a firm commitment to participative decision making. McLennan and Thurlow (2003:6) refer to an emerging paradigm, 'a growing emphasis on building relationships in education'. The development of SMTs in South African schools provides the potential for participative leadership but there is little empirical evidence to suggest that it is supplanting, or even supplementing, the principal's singular leadership.

Bush and Heystek (2003), Karlsson (2002) and Harber and Trafford (1999) point to the need for co-operation between principals and SGBs if governance is to be effective. Maile (2004) notes the importance of setting up democratic structures, but this requires thoughtful planning and parents need to be supported and informed. Karlsson [15], in a study of six schools, states that principals are dominant in all meetings because of: "their power position within the school, level of education in contrast to other members, first access to information taken from education authorities, and because it is the principal who executes the decisions taken”.

The Ministerial Committee's (2004:85) Review of School Governance shows that SGBs experience difficulties with SMTs in respect of lack of communication, failure to implement decisions taken at SGB meetings, and conflicts over spending priorities. However, SMTs report problems with the SGBs about members' availability, a lack of implementation of decisions taken at SGB meetings, a blurring of the distinction between SGB and SMT, and spending priorities. This authoritative report 
suggests that the ideal of participative decision-making is not yet a reality in many South African schools. The new ACE: School Leadership programme for aspiring principals (Department of Education, 2007) stresses participative leadership but it will take many years before such attitudes permeate the whole system.

Political and transactional leadership

Bush (2003) links transactional leadership to his political model. In political models, there is conflict between stakeholders, with disagreement being resolved in favour of the most powerful protagonists:

Transactional leadership is leadership in which relationships with teachers are based upon an exchange for some valued resource. To the teacher, interaction between administrators and teachers is usually episodic, short-lived and limited to the exchange transaction (Miller \& Miller, 2001: 182).

Miller and Miller's (2001) definition refers to transactional leadership as an exchange process. Exchange is an established political strategy for members of organizations. Principals possess authority arising from their positions as the formal leaders of their schools. However, the head requires the cooperation of educators to secure the effective management of the school. An exchange may secure benefits for both parties to the arrangement. The major limitation of such a process is that it does not engage staff beyond the immediate gains arising from the transaction. As Miller and Miller's definition implies, transactional leadership does not produce long-term commitment to the values and vision being promoted by school leaders.

Political theories have obvious relevance to the extended period of struggle against the Apartheid regime [2]. Badat [7, 21] argues that a constant feature of educational resistance has been what may be termed the politics of opposition. Key aspects of this politics have been mass mobilization and organization and mass action in pursuit of particular policy objectives and a non-racial and non-sexist democratic social order. Teacher unions act to protect the perceived interests of their members. One example of such action concerns the constitution of school governing bodies (SGBs). The South African Democratic Teachers' Union (SADTU) embarked on protest actions concerning the provision that parents should constitute a majority on the SGB (Sayed \& Carrim, 1997:93-95). The SGB itself is a political forum because it provides for the representation of sectional interests, creating the conditions for the increasing fragmentation of the education system.

Bush et al.'s (2006) review of the literature, for the Matthew Goniwe School for Leadership and Governance (MGSLG), provides ample evidence of political activity. The issue of learner discipline, for example, is widely regarded as having its roots in the era of protest against the apartheid government [4]). The desegregation of former white, Indian, and 'coloured' schools created certain disciplinary problems and cultural clashes

(De Meillon, 2001).

The Ministerial Committee's (2004) review of school governance notes that 20\% of the schools in their survey experienced conflict among members of the SGB while Shilote (2000) also reports conflict between SGB members and the principal. Bush and Joubert's (2004) large-scale research in Gauteng, for CfBT, shows that SGBs in seven of their 29 schools were perceived to be ineffective. This was often because of 'open conflict' between parents and educators.

Post-modern leadership

Bush (2003:127) notes that post-modern leadership aligns closely with his subjective model of management. Such theories, 
promulgated most vigorously by Greenfield (1973), assume that organisations have no ontological reality but are simply the creatures of the people within them, who may hold very different views. Similarly, Keough and Tobin (2001:2) say that "current postmodern culture celebrates the multiplicity of subjective truths as defined by experience and revels in the loss of absolute authority".

The post-modern model suggests that leaders should respect, and give attention to, the diverse and individual perspectives of stakeholders. They should also avoid reliance on the hierarchy because this concept has little meaning in such a fluid organisation. Starratt [5, 65] aligns postmodernity with democracy and advocates a "more consultative, participatory, inclusionary stance”, an approach consistent with participative leadership.

Sackney and Mitchell [7, 98] stress the importance of 'voice' in post-modern leadership. Stakeholders have a right to be heard. This fits the aspirations of 21st century South Africa. Principals need to facilitate participation by educators, parents, learners and the school community in all issues that affect their interests. The SGB is one vehicle for achieving this objective.

Moral leadership

This model assumes that the critical focus of leadership ought to be on the values, beliefs, and ethics of leaders themselves. Authority and influence are to be derived from defensible conceptions of what is right or good [11, 63]. Sergiovanni [8, 49] says that "excellent schools have central zones composed of values and beliefs that take on sacred or cultural characteristics". Subsequently, he adds that 'administering' is a 'moral craft' [6, 32].

West-Burnham [10] discusses two approaches to leadership, which may be categorized as 'moral'. The first he describes as 'spiritual' and relates to "the recognition that many leaders possess what might be called 'higher order' perspectives. These may well be ... represented by a particular religious affiliation”. Such leaders have a set of principles, which provide the basis of self-awareness. The second category is 'moral confidence', the capacity to act in a way that is consistent with an ethical system and is consistent over time.

Sergiovanni [19] argues that both moral and managerial leadership are required to develop a learning community:

In the principalship the challenge of leadership is to make peace with two competing imperatives, the managerial and the moral. The two imperatives are unavoidable and the neglect of either creates problems. Schools must be run effectively if they are to survive ... But for the school to transform itself into an institution, a learning community must emerge ... [This] is the moral imperative that principals face. The South African ACE: School Leadership materials (Department of Education, 2007:91) refer to the importance of spiritual intelligence and leadership. They also note Fullan's (2005:92) concept of 'moral purpose'. They conclude that "African society is built on a spiritual world in which answers and meaning are found". I will turn to African models of leadership at the end of this section.

Instructional leadership

Instructional leadership differs from the other models reviewed in this chapter because it focuses on the direction of influence, rather than its nature and source. The increasing emphasis on managing teaching and learning as the core activities of educational institutions has led to this approach being endorsed, notably by the English National College for School Leadership, which includes it as one of its ten leadership propositions.

Southworth (2002:79) says that "instructional leadership ... is strongly 
concerned with teaching and learning, including the professional learning of teachers as well as student growth". Bush and Glover's (2002:10) definition stresses the direction of the influence process:

Instructional leadership focuses on teaching and learning and on the behaviour of teachers in working with students. Leaders' influence is targeted at student learning via teachers. The emphasis is on the direction and impact of influence rather than the influence process itself.

Southworth's (2002) qualitative research with primary heads of small schools in England and Wales shows that three strategies were particularly effective in improving teaching and learning: modelling; monitoring; and professional dialogue and discussion.

Instructional leadership is a very important dimension because it targets the school's central activities, teaching and learning. However, this paradigm underestimates other aspects of school life, such as sport, socialisation, student welfare, and self esteem [1, 64].

The South African Task Team report [14] stressed that management is important because it provides a supportive framework for teaching and learning:

Management in education is not an end in itself. Good management is an essential aspect of any education service, but its central goal is the promotion of effective teaching and learning ... The task of management at all levels in the education service is ultimately the creation and support of conditions under which teachers and their students are able to achieve learning ... The extent to which effective learning is achieved therefore becomes the criterion against which the quality of management is to be judged.

Despite this authoritative comment, which would be echoed in many other countries, there is only limited evidence of principals and other school leaders being developed for the central function of schools promoting learning. Bush and Heystek's (2006) research in Gauteng showed that only $27.2 \%$ of survey principals identified this topic as a training need. These findings suggest that principals are not conceptualising their role as 'leaders of learning'. Given the radical changes in school governance and management, it is understandable that principals wish to give priority to financial and staff management, and to relationships with governing bodies. However, school improvement ultimately depends on school leaders accepting their responsibility for developing learning.

McLennan and Thurlow [20] refer to the absence of a 'culture of teaching and learning' in South African schools: "The virtual collapse of the culture of teaching and learning in many urban and rural schools has eroded the confidence of education managers. They have little idea of what would be required to restore the culture".

Giving a prominent place to leadership for learning within principals' training and development programmes would make a valuable contribution to the restoration of an appropriate culture of teaching and learning and to the development of schools as learning organisations (Thurlow, 2003). This is recognized by the South African Department of Education, which stresses the importance of learning in its ACE: School Leadership materials (Department of Education, 2007). Contingent leadership.

The models of leadership examined earlier in this section are all partial. They provide valid and helpful insights into one particular aspect of leadership. Some focus on the process by which influence is exerted while others emphasize one or more dimensions of leadership. However, none of these models provides a complete picture of school leadership.

The contingent model provides an alternative approach, recognizing the 
diverse nature of school contexts and the advantages of adapting leadership styles to the particular situation, rather than adopting a 'one size fits all' stance:

This approach assumes that what is important is how leaders respond to the unique organizational circumstances or problems ... there are wide variations in the contexts for leadership and that, to be effective, these contexts require different leadership responses ... individuals providing leadership, typically those in formal positions of authority, are capable of mastering a large repertoire of leadership practices. Their influence will depend, in large measure, on such mastery (Leithwood et al., 1999:15). South Africa has one of the most diverse education systems in the world. It ranges from wellendowed city schools, comparable to the best in developed countries, to very poor schools without access to the most basic facilities, such as water, power, and sanitation. Given such disparities, it is unwise to prescribe one universal approach to school leadership and management. It is much better to equip principals with a 'tool kit' of skills and the wisdom to know which approaches should be applied in the particular circumstances they are required to manage.

Yukl (2002:234) notes that "the managerial job is too complex and unpredictable to rely on a set of standardised responses to events". Leadership requires effective diagnosis of problems, followed by adopting the most appropriate response to the issue or situation [17]. This reflexive approach is particularly important in periods of turbulence when leaders need to be able to assess the situation carefully and react as appropriate rather than relying on a standard leadership model.

African models of leadership

All the models discussed hitherto emerged from highly developed western countries. Bush's [11] treatment of these models has been adapted for use in South African university programmes on school management, and in the ACE: School Leadership course (Department of Education, 2007). However, there is an emerging recognition that African models also have much to offer in interpreting management practice and in understanding the behaviour of school leaders and communities.

The most frequently cited African model is Ubuntu. According to Mbigi [18], Ubuntu means collective personhood and collective morality. "Our black African cultural heritage places a great emphasis on and has great concern for people. Emphasis is also placed on being a good person". He adds that Ubuntu "should be reflected in our modern education" [19].

Msila (in preparation) states that $U b u n t u$ is one of the fundamental values of the South African constitution. $U b u n t u$ is rooted in African traditional society and it espouses the ideal of interconnectedness among people. He links $U$ b un $t u$ to democracy, claiming that it is the 'ideal democratic tenet' and contributes to 'a world of moral stability'.

The ACE: School Leadership course (Department of Education, 2007) introduces the concept of the Lekgotla. The leader or kgosi should adopt an approach that "inspires trust in the decision-making process". Such a leader "operates on the basis of a natural belief in humanity, who gives without expecting anything and listens without prejudice, creating a climate of trust. Trust is the basis of inspiration, motivation and creativity" [17].

There has been little empirical work underpinning these African concepts but Msila (in preparation) has applied it to his study of management in township schools. A new principal took over a dysfunctional school and sought to adopt a more democratic approach. She "moved for a more inclusive approach to management. The idea of the collective is very basic to 
the $U b u n t u$ philosophy, which she was consciously trying to implement. She was changing the leadership paradigm in the school”. Msila concludes that the principles of $U b u n t u$ are well suited to leadership in the new South Africa.

There are obvious connections between these African concepts and the western participative and moral leadership models. They share the emphasis on collective and humane values and on managing by consent. More research is required to assess whether, how, and to what extent $U b u n t u$ and the Lekgotla influence school leadership in the new South Africa.

Article submission date 15. 02.2013

\section{BIBLIOGRAPHY}

1. Bolman LG \& Deal TE 1997. Reframing Organizations: artistry, choice and leadership. San Francisco, CA: Jossey Bass. Bottery M 2001. Globalisation and the UK competition state: no room for transformational leadership in education? School Leadership and Management, 21:199-218.

2. Bush T. 1986. Theories of Educational Management. London: Harper and Row. Bush T 1995. Theories of Educational Management, 2nd edn. London: Paul Chapman.

3. Bush T. 1998. The National Professional Qualification for Headship: the key to effective school leadership? School Leadership and Management, 18:321-334.

4. Bush T. 1999. Crisis or Crossroads? The Discipline of Educational Management in the Late 1990 s. Educational Management and Administration, 27: 239-252.

5. Bush T. 2003. Theories of Educational Management, 3rd edn. London: Sage.

6. Bush T. (in press). Leadership and Management Development in Education. London:

7. Bush T. \& Anderson L. 2003. Organizational culture. In: T Bush, M Coleman \& M Thurlow (eds). Leadership and Strategic Management in South African Schools. London: Commonwealth Secretariat.

8. Bush T. \& Glover D. 2002. School Leadership: Concepts and Evidence. Nottingham: National College for School Leadership.

9. Bush T. \& Heystek J. 2003. School governance in the new South Africa. Compare, 33:127-138.

10. Bush T. \& Joubert R. 2004. Education Management Development and Governor

11. Training in Gauteng: An Overview. Paper presented at the EMASA Conference,

12. Port Elizabeth, May. Bush T \& Heystek J 2006. School leadership and management in South Africa:

13. Principals' perceptions. International Studies in Educational Administration, 34:63-76.

14. Bush T., Bisschoff T., Glover D., Heystek J., Joubert R. \& Moloi K. 2006. School Leadership, Management and Governance in South Africa: A Systematic Literature Review. Johannesburg: Matthew Goniwe School of Leadership and Governance.

15. Caldwell B. 1992. The principal as leader of the self-managing school in Australia.

16. Journal of Educational Administration, 30:6-19. Caldwell B \& Spinks J 1992. Leading the SelfManaging School. London: The Falmer Press.

17. Carrim N. \& Shalem Y. 1 999. School effectiveness in South Africa. Qualitative Studies in Education, 12:59-83. Chirichello M 1999. Building Capacity for Change: Transformational Leadership for

18. School Principals. Paper presented at ICSEI Conference, San Antonio, January 3-6.

19. Cuban L. 1988. The Managerial Imperative and the Practice of Leadership in Schools.

20. Albany, NY: State University of New York Press. Day C, Harris A \& Hadfield M 2001. Challenging the orthodoxy of effective school leadership. International Journal of Leadership in Education, 4:39-56. De Liefde W 2003. Lekgotla: The Art of Leadership through Dialogue. Jacana

21. Education, South Africa. De Meillon N 2001 . Interpersonal relationships in multiracial schools in a South 
22. African context. International Journal of Group Tensions, 30:135-159. Department of Education 1996. Changing $M$ anagement to Manage Change in

23. Greenfield TB 1973. Organisations as social inventions: rethinking assumptions about change. Journal of Applied Behavioural Science, 9:551-574. Harber C \& Trafford B 1999. Democratic management and school effectiveness in two countries: a case of pupil participation. Educational Management and Administration, 27:45-54. Huber S 2004. Preparing School Leaders for the 21st Century: An International Comparison of Development Programs in 15 Countries. London: Routledge Falmer.

24. Karlsson J. 2002. The role of democratic governing bodies in South African schools.

25. Comparative Education, 38:327-336. Keough T \& Tobin B 2001. Postmodern Leadership and the Policy Lexicon: From

26. Theory, Proxy to Practice. Paper for the Pan-Canadian Education Research

27. Agenda Symposium, Quebec, May. Leithwood K 1 994. Leadership for school restructuring. Educational Administration

28. Quarterly, 30:498-518.

29. Leithwood K., Jantzi D. \& Steinbach R. 1999. Changing Leadership for Changing

30. Times. Buckingham: Open University Press. Lemon A 2004. Redressing school inequalities in the Eastern Cape, South Africa.

31. Journal of South African Studies, 30:269-290. Maile S 2004. School choice in South Africa. Education and Urban Society,

32. 37:94-116.

33. Mbiga L. 1997. Ubuntu: The African Dream in Management. Randburg, SA: Knowledge Resources.

34. McLennan A. \& Thurlow M. 2003. The context of education management in South Africa. In: Thurlow M, Bush T \& Coleman M (eds). Leadership and Strategic Management in South African Schools. London: Commonwealth Secretariat.

35. Miller TW \& Miller JM 2001. Educational leadership in the new millennium: a vision for 2020. International Journal of Leadership in Education, 4:181-189.

36. Ministerial Review Committee 2004. Review of School Governance in South African Public Schools. Pretoria: Department of Education.

37. Morgan G. 1 997. Images of Organization.. Newbury Park, CA: Sage.

38. Msila V. (in preparation). Ubuntu and school leadership: A panacea for failing township schools?

39. Pandor NG 2006. Address to the South African Principals Association, Limpopo, 9 June.

40. Sackney L. \& Mitchell C. 2001. Postmodern expressions of educational leadership. In: K Leithwood \& P Hallinger (eds). The Second International Handbook of Educational Leadership and Administration. Dordrecht: Kluwer.

41. Sebakwane S. 1997. The contradictions of scientific management as a mode of controlling teachers' work in black secondary schools: South Africa. International Journal of Educational Development, 17:391-404.

42. Sergiovanni T. 1984. Leadership and excellence in schooling. Educational Leadership, 41:4-13.

43. Shilote NC 2001. An Exploration of Community Engagement with Governance in a Rural Northern Province School. Unpublished thesis, Johannesburg: Rand

44. Leadership and Management, 17:231-243. Yukl GA 2002. Leadership in Organizations, 5th edn. Upper Saddle River, NJ: Prentice-Hall. 


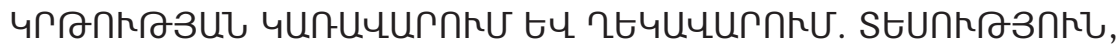

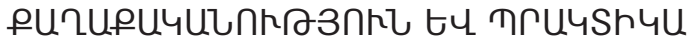

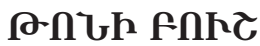

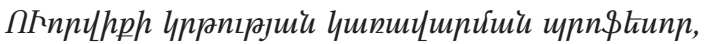

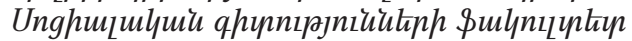

\section{9กก UUPQUU3U}

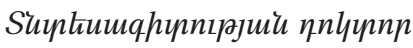

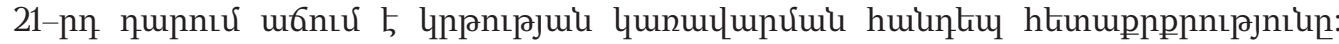

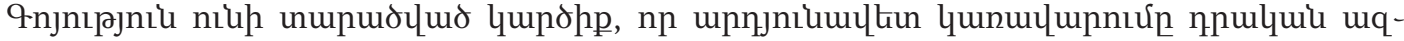

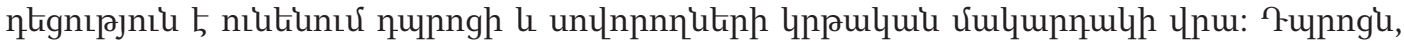

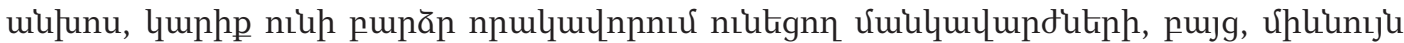

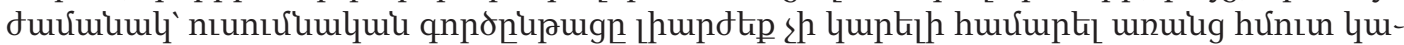

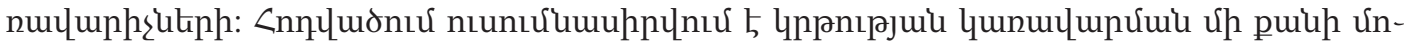

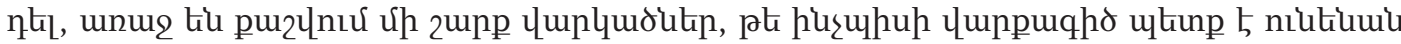

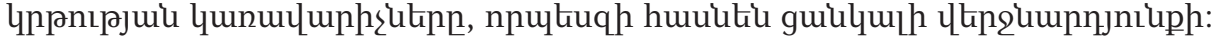

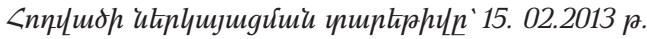

\section{ПЕДАГОГИЧЕСКОЕ РУКОВОДСТВО И МЕНЕДЖМЕНТ - ТЕОРИЯ, СТРАТЕГИЯ И ПРАКТИКА}

\section{БУШ ТОНИ}

Уорикский университет, факультет

социальных наук,

профессор педагогики

\section{САРКИСЯН ГОР}

Доктор экономических наук

В начале 21-го века возрос интерес к педагогическому руководству из-за получившего распространение мнения, что квалификация руководства оказывает значительное влияние на результаты школы и учеников. Также распространяется понимание того, что для обеспечения наилучшего возможного образования для своих учеников школам необходимы эффективные руководители и менеджеры. Бесспорно, школам нужны квалифицированные и преданные делу учителя, но они, в свою очередь, нуждаются в руководстве высокоэффективных директоров и поддержке менеджеров. В то время как необходимость в эффективных руководителях широко признана, гораздо меньше уверенности в том, какие лидерские качества наиболее вероятно обеспечат благоприятные результаты. В статье описаны теоретические основы для развития поля педагогического руководства и менеджмента, дана оценка разным моделям руководства и рассмотрена их сравнительная эффективность в достижении успешности школ. 